Department of Reproduction, Research Institute for Animal Brecding and Nutrition, Herceghalom, Hungary ${ }^{\prime}$ and Department of Reproductive Biology, Research Institute for the Biology of Farm Animals, Dummerstorf, Germany?

\author{
ISTVAN EGERSZEGI', HELMUT TORNER ${ }^{2}$, JOSZEF RÁTKY' \\ and KLAUS-PETER BRÜSSOW ${ }^{2}$
}

\title{
Follicular development and preovulatory oocyte maturation in Hungarian Mangalica and Landrace gilts
}

\author{
Dedicated to Prof. Dr. Dr. he. mult. Horst Kräußlich on the occasion of his \\ $75^{\text {th }}$ birthday
}

\section{Summary}

Preservation of native pig breeds of different values has got increasing public interest. Hungarian Mangalica, likewise other native races, became uninteresting because of economic reasons or other characteristics, and were replaced by modem breeds. Its population decreased rapidly and reached a critical level. However, the exceptional taste of the meat, and the robustness and motherliness do support the propagation of this breed. Nevertheless, low prolificacy and marked seasonality remains a problem. The aim of the present study was to find possible implications of the physiological basis with regard to the low fecundity. Therefore, preovulatory follicular development and intrafollicular oocyte maturation of Mangalica and of Landrace gilts were compared. A total of 18 pubertal Blond and Swallow Belly Mangalica and 19 Landrace gilts $(8.5$ to 9 month of age, body weight of 120 to $125 \mathrm{~kg}$ ) werc used. Oestrus of gilts was synchronized by feeding Regumate", follicular growh was stimulated by administering 1,000 IU PMSG $24 \mathrm{~h}$ after the last Regumate ${ }^{\circ}$ feeding and the L.H peak simulated with $750 \mathrm{IU}$ hCG $80 \mathrm{~h}$ after PMSG.

Cumulus-oocyte-complexes (COCs) were recovered $34 \mathrm{~h}$ after hCG by endoscopic Ovum Pick Up. Follicular fluids from follicles per ovary were pooled and the morphology of COCs was determined. COCs were classified as compact, expanded or denuded. Thereafter, COCs were prepared for evaluation of nuclear configuration. Based on their nuclear status the oocytes were classified as 1) immature - germinal vesicle (GV), with diplotene chromatin; 2) meiosis resumedGV breakdown, diakinesis, M-I to A-I; or 3) mature - T-I and M-II.

The average number $( \pm S D)$ of preovulatory follicles was $6.8 \pm 1.4$ in Mangalica and $19.6 \pm 6.6$ in Landrace gilts $(\mathrm{p}<0,05)$. Differences were obtained concerning the morphology of recovered COCs between breeds. The per cent of oocytes with compact cumulus was higher in Mangalica compared to Landrace gilts ( 31 vs. $16 \%$ ) but less oocytes possess expanded cumulus ( $62 \mathrm{vs} .78 \%, \mathrm{p}<0.05)$. The meiotic configuration of oocytes was unlike between Mangalica and Landrace gilts. The rate of oocytes with mature chromatin configuration (Telophase I IMetaphase II) was higher ( 27 vs, $62 \%, p<0.05)$ in Landrace sows.

It is assumed that both diminished follicular development and protracted intrafollicular oocyte maturation may be involved in low fecundity in Mangalica.

Key Words: follicle, cumulus-oocyte-complex, meiotic configuration, Mangalica, swine

\section{Zusammenfassung}

Titel der Arbeit: Follikelentwicklung. und präovulatorische Eizellreifung bei Ungarischen Mangalitza und Landrasse Jungsauen

Der Erhalt genetisch wertvoller einheimischer Schweinerassen trifft auf ein wachsendes bffentliches Interesse. Die Ungarischen Mangalitza wurden ăhnlich wie andere bodenständige Rassen ökonomisch uninteressant und durch modeme Schweinerassen ersetzt. Der aussergewohnliche Fleischgeschnack, die Robustheit und die Mütterlichkeit der Sauen sind jedoch Grunde für die Erhaltung der Mangalitza. Die geringe und saisonbedingte Fruchtbarkeit ist jedoch ein bestehendes Problem. Ziel der Untersuchung war es, mögliche physiologische Ursachen der geringen Fruchtbarkeit aufzuzeigen. Deshalb wurden Follikel- und intrafollikuläre Eizellentwicklung von Ungarischen Mangalitza im Vergleich zu Landrasse Sauen untersucht.

Insgesamt 18 zyklische Blonde und Schwalbenbăuchige Mangalitza sowie I9 Landrasse Jungsauen (Alter 8,5-9 
Monate, 120-125 kg Korpermasse) wurden untersucht. Der Östrus wurde mit Regumate ${ }^{\Phi}$ synchronisiert und das Follikelwachstum mit 1000 IE PMSG $24 \mathrm{~h}$ nach der letzten Regumate ${ }^{\circ}$-Futtenung stimuliert. Der LH-Peak wurde durch 750 IE hCG $80 \mathrm{~h}$ nach PMSG simuliert.

Cumulus-Oozyten-Komplexe (COCs) wurden 34 h nach hCG mittels endoskopischen Ovum-Pick-Up gewonnen. Die COCs wurden je Ovar zusammengefasst und anhand der Cumuluszell-Morphologie als kompakt, expandiert oder nackt klassifiziert. Anschliessend erfolgte eine Untersuchung des Zellkernzustandes. Anhand der Kernkonfiguration wurden die Oozyten wie folgt beurteilt: 1) unreif - Germinalvesikel (GV), mit diplotänem Chromatin; 2) Wiederaufnahme der Meiose - GV breakdown, Diakinese, M-1 bis A-1; 3) reif - T-1 und M-II.

Die mittlere Anzahl $( \pm S D)$ der präovulatorischen Follikel betrug $6,8 \pm 1,4$ bei den Mangalitza und $19,6 \pm 6,6$ bei den Landrasse Jungsauen $(p<0,05$ ). Unterschiede wurden in der COC-Morphologie zwischen beiden Rassen ermittelt. Der Anteil von Eizellen mit kompaktem Cumulus war bei den Mangalitza hőher (3t vs. $16 \%$ ), jedoch weniger Oozyten wiesen einen expandierten Cumulus auf (62 vs, $78 \%, \mathrm{p}<0,05)$. Die Meiosekonfiguration der Oozyten war ebenfalls unterschiedlich. Der Anteil von Oozyten mit reifem Chromatin (Telophase I/Metaphase II) war bei Landrasse Jungsauen vergleichsweise høher ( 27 vs. $62 \%$, p0,05).

Es wird angenommen, dass sowohl eine geringere Follikelentwicklung als auch eine verzögerte intrafollikuläre Eizellreifung ursächlich an der geringen Fruchtbarkeit der Mangalitza beteiligt sind.

Schlüsselwörter: Follikel, Eizelle, Meiose, Mangalitza, Schwein

\section{Introduction}

Native and endangered swine breeds with different genetic, commercial and/or cultural value have been more and more in the focus of interest. Hungarian Mangalica, presented by three types, i.e. Blond, Red and Swallow Belly Mangalica, is a value aboriginal pig breed. Although Mangalica was the most typical pig breed in Hungary till the early fifties, it disappeared quickly from the pig industry and was replaced by modern breeds. The population decreased rapidly and reached a critical level till the eighties and is limited to actually 507 sows (ZENGÖ, 1998). The reason of the fast decrease and nearly disappearance of this breed is that the Mangalica cannot fulfill the requirements of modern industrial swine production. So their reproductive characteristics are much more poor compared to modern breeds. Puberty attains at 9 12 months of age. The mean age at first farrowing is $572 \pm 96$ days, $1.5 \pm 0.1$ litter/year can be achieved and the mean litter size is $5.7 \pm 0.8$ (BALTAY, 1983; SZABÓ, 1999). The rearing period is $6-7$ week long. However, it is worth mentioning that normally there is no difference between the number of born and weaned piglets. Other big problem is that sows come in heat usually at the end of spring and at beginning of autumn. If there is any estrous in other periods of the year, both the symptoms and fertility are weak. This kind of seasonality alone would be enough to be unacceptable for intensive breeding system. Furthermore, the fattening time is much longer compared to white breeds, i.e. before about 16 months of age there is no sense to slaughter them. Moreover the meat quality is little acceptable for the up to date human dietary habits, but the taste of the meat is undoubtedly delicious. The Mangalica meat is resembling very much to that of the Iberian swine and special meat products are quite comparable to the world famous Serrano ham. The clean meat yield is between $30.5-35 \%$ compared to more than $50 \%$ of modern white breeds (KRALOVÁNSZKY, 1996).

Beside quality and taste of the meat, noteworthy characteristics of the Mangalica breed are its very well adaptation to extensive housing conditions and extreme temperature, and marked motherliness. In the course of the last five years the propagation of Mangalica has met progressive public support (RÁTKY et al., 2000). So the German 
Safeguard Society of Ancient and Endangered Domestic Animal Breeds even named in 1999 the Mangalica for the breed of the year. Enthusiastic swine breeders in Austria, Germany and Switzerland keep about 500 Mangalica pigs.

Efforts were done to propagate Mangalica by breeding strategies and by means of biotechnique (RÁTKY et al., 2001). Little is known about the physiological reason of low fertility in Mangalica. It was shown (RÁTKY and BRÜSSOW, 1998) that Mangalica gilts have an ovarian reaction similar to Landrace if follicular development and ovulation are stimulated with exogenous gonadotropins. The aim of the present experiment was to find out possible differences in the preovulatory follicle development and intrafollicular oocyte maturation between Mangalica and Landrace gilts.

\section{Materials and Methods}

A total of 18 pubertal Blond and Swallow Belly Mangalica and 19 Landrace gilts aged 8.5 to 9 month with a body weight of 120 to $125 \mathrm{~kg}$ were used. Gilts were synchronized by feeding Regumate $^{\infty}$ (16 mg altrenogest/animal daily, Serum Werk Bernburg) for 15 days. Follicular growth was stimulated by administering 1,000 IU im PMSG (Folligon ${ }^{\circledR}$, Intervet, $24 \mathrm{~h}$ after the last Regumate ${ }^{2}$ feeding $(0800 \mathrm{~h})$. The LH peak was simulated with 750 IU hCG (Choriogonin ${ }^{8}$, Richter Gedeon, $80 \mathrm{~h}$ after PMSG.

Cumulus-oocyte-complexes (COCs) were recovered $34 \mathrm{~h}$ after hCG by endoscopic Ovum Pick Up as described by BRÜSSOW and RÁTKY (1994). Follicular aspiration was carried out via a two-way cannula (40 mm length, 16-gauge) and an electric aspiration pump (model 3014, Labotect, Göttingen) with an initial vacuum of $100 \mathrm{~mm} \mathrm{Hg}$ corresponding to a volume of $17 \mathrm{ml} / \mathrm{min}$. The tip of the aspiration cannula was inserted into a follicle, the follicular content was aspirated, and the follicle was refilled and aspirated twice with heparinized PBS. Only macroscopic healthy follicles, well vascularized and translucent, and with a diameter of $>5 \mathrm{~mm}$ were punctured.

Follicular fluids from different follicles per ovary were pooled. The morphology of freshly recovered COCs was determined using an inverted microscope at $x 60$ magnification. COCs were classified as compact, expanded or denuded (TORNER et al., 1998). After classifying, the COCs were immediately prepared for evaluation of nuclear configuration. Removal of cumulus cells was accomplished in PBS containing $100 \mathrm{IU} / \mathrm{ml}$ hyaluronidase (hylase, Impfstoffwerk Dessau) followed repeated pipetting with a fine-bore glass pipette. Oocytes were mounted on slides and fixed for $>24 \mathrm{~h}$ in a mixture of acetic acid/alcohol/chloroform $(3: 6: 1)$ before staining with $2 \%$ orcein in $60 \%$ acetic acid. The nuclear configuration of oocytes was examined using phase-contrast optics at $\times 250$ to $\times 630$ magnification. Based on their nuclear status the oocytes were classified as 1) immature germinal vesicle (GV), with diplotene chromatin; 2) meiosis resumed - GV breakdown, diakinesis, M-I to A-I; or 3) mature - T-I and M-II.

Data were analysed by Students t-test and Chi-square, respectively, and $p<0.05$ was considered to be statistically significant.

\section{Results}

The average number $( \pm \mathrm{SD})$ of preovulatory follicles was $6.8 \pm 1.4$ in Mangalica and $19.6 \pm 6.6$ in Landrace gilts $(\mathrm{p}<0.05)$. The size of punctured preovulatory follicles 
ranged between 5 to $7 \mathrm{~mm}$ in Mangalica and 6 to $9 \mathrm{~mm}$ in Landrace. Altogether 298 follicles were punctured and 183 COCs recovered. In Mangalica gilts a lower recovery rate of COCs was achieved. Differences were obtained concerning the morphology of recovered COCs between breeds (Table 1 ).

Table 1

Number of punctured follicles and aspirated COCs, and morphology of COCs in Mangalica and Landrace gilts $(n=37)$ (Anzahl punktierter Follikel und aspirierter COCs sowie COC-Morphologie bei Mangalitza und Landrasse Jungsauen)

\begin{tabular}{lccc}
\hline & & Mangalica & Landrace \\
\hline No. of aspirated follicles & $\mathrm{n}$ & 108 & 190 \\
No. of recovered COC & $\mathrm{n}$ & 58 & 125 \\
Recovery rate & $\%$ & $53.7^{\mathrm{a}}$ & $65.8^{\mathrm{b}}$ \\
\hline COC morphology & $\%$ & & $16^{\mathrm{b}}$ \\
$\quad$ compact & $\%$ & $31^{\mathrm{b}}$ & $78^{\mathrm{b}}$ \\
$\quad$ expanded & $\%$ & $62^{\circ}$ & 6 \\
$\quad$ denuded & $\%$ & 7 &
\end{tabular}

The per cent of oocytes with compact cumulus was higher in Mangalica compared to Landrace gilts $(\mathrm{p}<0.05)$. However, most $(62$ and $78 \%, \mathrm{p}<0.05)$ COCs aspirated from the preovulatory follicles possess expanded cumulus. Although only macroscopically healthy follicles were aspirated, 6 to $7 \%$ of the COCs were denuded but without differences between breeds.

The meiotic configuration of oocytes was unlike between Mangalica and Landrace gilts (Table 2).

Table 2

Chromatin configuration of oocytes recovered from Mangalica and Landrace gilts ( $\mathrm{n}=37)$ (Chromatinkonfiguration in Oozyten von Mangalitza und Landrasse Jungsauen)

\begin{tabular}{lccc}
\hline & & Mangalica & Landrace \\
\hline No. of evaluated oocytes & $\mathrm{n}$ & 44 & 118 \\
Chromatin Configuration & $\%$ & & \\
$\quad$ immature (GV) & $\%$ & $18^{\mathrm{a}}$ & $6^{\mathrm{b}}$ \\
resumption of meiosis (GVBD - Al) & $\%$ & $55^{\mathrm{a}}$ & $32^{\mathrm{b}}$ \\
$\quad$ mature (T I/M II) & $\% 2^{\mathrm{a}}$ & $62^{\mathrm{b}}$ \\
\hline Twithin a row p<0.05 (Chi-squarc) & & &
\end{tabular}

The rate of oocytes with mature chromatin configuration (Telophase I /Metaphase II) was higher $(\mathrm{p}<0.05)$ in Landrace sows. Correspondingly, the proportion of immature oocytes or of oocytes in resumption of meiosis was lower compared to Mangalica.

\section{Discussion}

Preservation of native pig breeds of different values has found increasing public interest. Likewise Mangalica - the most typical pig breed in Hungary till the early fifties - quickly disappeared from the pig industry because of meat quality and reproduction. However, in the recent years there is again an increase in the number of the stock. The exceptional taste of the meat, and the robustness and motherliness do support the propagation of this breed. Nevertheless, low prolificacy and marked seasonality remain problem. The aim of the present study was to find possible 
implications of the physiological basis with regard to the low fecundity. Therefore preovulatory follicular development and intrafollicular oocyte maturation of Mangalica and of Landrace gilts were compared. Differences have been shown in follicular development and oocyte maturation between European white breeds and high prolific Chinese Meishan (HUNTER et al., 1993).

Except the results of RÁTKY and BRÜSSOW (1998) there are no data on the number of follicles in Mangalica. After slaughter of 10 sows, a mean number of $11.5 \pm 2.1$ ovulated follicles was recorded. Sows at the age of $<2.5$ year had less corpora lutea as older sows (10.6 \pm 1.0 vs. $12.6 \pm 1.5)$. The application of exogenous gonadotropins (750, 1000 or 1250 IU PMSG) to Mangalica gilis stimulated growth of $13.7 \pm 3.1,24.2$ \pm 2.5 and $21.0 \pm 2.9$ follicles, respectively. Those results were comparable to PMSG stimulation of gilts of white breeds. In the present study Mangalica gilts grow only 6.8 \pm 1.4 follicles. A significant higher number of follicles was stimulated in Landrace gilts $(19.6 \pm 6.6, \mathrm{p}<0.05)$. Differences in the number of follicles compared to the results of RÁTKY and BRÜSSOW (1998) can be mediated on season. Their experiments were carried out in May but the present one in the end of November. Mangalica express spontaneous heat usually only in the end of spring and the beginning of autumn.

Differences were obtained in cumulus morphology between Mangalica and Landrace gilts. Cumulus expansion was lower in Mangalica (62 vs. 78 \%). Cumulus morphology dramatically changes during preovulatory maturation. The uncoupling between oocyte and cumulus starts in vivo about $22 \mathrm{~h}$ after LH peak or hCG, respectively (CRAN, 1985, TORNER et al., 1998). In German Landrace gilts nearly all COCs (98\%) expressed expanded cumulus $34 \mathrm{~h}$ after hCG (TORNER et al,, 1998). The lower degree of cumulus expansion in Mangalica may be attributed to a more protracted follicle and oocyte maturation.

More oocytes with immature chromatin configuration were found in Mangalica (18 vs. $6 \%$ ). This result is reasonable because as aforementioned a higher portion of oocytes with compact cumulus was found in Mangalica. A relationship between cumulus morphology and oocyte meiotic maturation has been demonstrated, where most oocytes with compact cumulus are in GV-stage (TORNER et al., 1998). However, the majority of oocytes of both breeds resumed meiosis ( 82 and $94 \%$ ). Complete GV breakdown was as well observed in gilts 24 to $36 \mathrm{~h}$ after the preovulatory LH surge (GUTHRIE and GARRETT, 2000). The percentage of mature oocytes (T I/M II) was still lower in Mangalica. Differences in oocyte maturation has been mentioned between white hybrid and prolific Meishan gilts. During the immediate preovulatory period ( $36 \mathrm{~h}$ after the onset of behavioural oestrus in white gilts and $42 \mathrm{~h}$ in Meishan) the portion of oocytes in the meiotic stage anaphase I to metaphase II was 53.4 and $87.9 \%$ (FAILLACE and HUNTER, 1994). It was suggested that the advanced oocyte maturation in follicles of Meishan pigs may be important for ensuring the prolificacy of this breed. Conversely in Mangalica, the lower fecundity may be partially due to delayed oocyte maturation. However this speculation has to be supported by further experiments. Additional studies have to be done regarding intrafollicular hormone envitonment and oocyte maturation. It is evident from the literature that the intrafollicular hormone content has a severe effect (THIBAULT et al., 1987; DING 
and FOXCROFFT, 1992; HUNTER et al., 1992). However, it is necessary to mention here that the low number of available Mangalica gilts and their ovarian reaction make extensive experiments more difficult.

In conclusion, it has been demonstrated that less oocytes have expressed cumulus expansion and matured through to metaphase II within the immediate preovulatory period ( $34 \mathrm{~h}$ after hCG) in Mangalica than in Landrace gilts. Furthermore, a lower number of preovulatory follicles were found. It is assumed that both diminished follicular development and protracted intrafollicular oocyte maturation may be involved in low fecundity in Mangalica. However, there is a total lack of information on hormone secretion and follicular development during the oestrous cycle, and on early embryonic development in Mangalica. Consequently, more profound experiments are necessary to investigate the diversity of these complex processes.

\section{Acknowledgment}

The authors thank Mr. Peter Toth from Olmos-Toth Ltd for providing Mangalica gilts and the staff of the Mangalica Production Unit Nyiribrony for technical belp.

The study was supported by the Hungarian and German Ministries of Agriculture, project $11 / 93$.

BALTAY, M:

\section{References}

Hungarian swine and hybrid breeds. (Magyarországi sertésfajták és - hibridek) Mezögazdasảgi Kiado (1983), 43-53

BRUSSOW, K.-P.; RATKY, J.:

CRAN, D,G:

Endoscopic collection of porcine embryos. Reprod. Dom. Anim. 31 (1996), 711-715

Qualitative and quantitative structural changes during pig oocyte maturation. J. Reprod. Fertil. 74 (1985), 237-245

DING, J.C.; FOXCROFFT, G.R.:

Follicular heterogeneity and oocyte maturation in vitro in pigs. J. Reprod. Fertil. 47 (1992), 648-655

HUNTER, M.G.; BIGGS, C.; FAILLACE, L.S.: Endocrine and follicular study in Meishan pigs. J. Reprod. Fertil. Suppl. 48 (1993), 261-270

HUNTER, M.G.; BIGGS, C.; FAILLACE, L.S.; PICTON, H.M.:

Current concepts of folliculogenesis in monovular and polyovular farm spiecies. J. Reprod. Fertil. Suppl. 45 (1992), 23-38

FAILLACE, L.S.; HUNTER, M.G.

Follicle development and oocyte maturation during immediate preovulatory period in Meishan and white hybrid gilts. J. Reprod. Fertit. 101 (1994), 571-576

KRALOVẢNSZKY, U.P:

Change of swine breeds. (Sertések fajtaváltása) Állattenyéssztơk Lapja 11 (1996), 6

RATKY, J,; BRÜSSOW, K.-P.:

Ovarian activity in gilts including some characteristics of a native breed. Reprod. Dom. Anim, 33 (1998), 219-222

RATTKY, J,; BRÜSSOW, K.-P.; EGERSZEGI, L; TORNER, H.; SOLTI, L.: Mangalica - an old pig breed with actual interest and its propagation by means of biotechnique. A.E.T.E. Newsletter No. 13 (2000), 6-10

RATKY, J.; BRÜSSOW, K.-P.; SOLTI, L.; TORNER, H.; SARLOS, P.: Ovarian response, embryo recovery and results of embryo transfer in a Hungarian native breed.

SZABO, P.: Theriogenology (2001), in press

Manganica. (A manganica) Kistermelok Lapja 12 (1999), 14-15 
THIBAULT, C., SZÖLLOSI, D.; GERARD, M.:

Mammalian oocyte maturation. Reprod. Nutr. Dev. 27 (1987), 865-896

TORNER, H.; BRÚSSOW, K.-P,; ALM, H.; RÁTKY; J.:

Morphology of porcine cumulus-oocyte-complexes depends on the stage of preovulatory maturation. ZENGÖ, Á,: Theriogenology 50 (1998), 39-48

Present and future of Mangalica. (A mangalica jelene és Jðvひoje) A Sertés 1 (1998), 4-7

Received: 2001-02-14

Accepted: 2001-05-04

Authors' addresses

Dipl. Agrar-Ing. ISTVAN EGERSZEGl

Prof, Dr. med. vet, et agr. habil JOZSEF RATKY

Research Institute for Animal Breeding and Nutrition

H-2053 Herceghalom

Hungary

Dr. rer. nat. HELMUT TORNER

Dr. rer, nal. habil KLAUS-PETER BRÜSSOW*

Research Institute for the Biology of Farm Animals

Wilhelm-Stahl-Allee 2

D-18196 Dummerstorf

Germany

- Corresponding author

E-Mail: bruessow@Bon-dummerstorf.de 


\title{
Buchbesprechung
}

\author{
Fleckvieh - Entwicklung zu einer Weltrasse
}

GOTTFRIED AVERDUNK, ALFONS GOTTSCHALK, MAXIMILIAN PUTZ, EWALD ROSENBERGER

286 Seiten, 194 Farbfotos, 90 s/w Fotos, 15 farbige Zeichnungen, 105 Tabellen, BLV Verlagsgesellschaft Munchen, Zürich, Wien, 2001, ISBN 3-405-16238-6, DM 49,90; 6S 364,00; sFr 44,50

Mit der in diesem Buch vorgestellten Aufarbeitung des historischen Werdeganges der Fleckviehrasse haben sich die Autoren ein bleibendes. Verdienst in der deutschen Tierzuchtliteratur erworben. Die sehr kompetente, seit Jahrzehnten im Zentrum der deutschen Fleckviehzucht und an der Entwicklung dieser Rasse maßgeblich wirkende Autorengruppe, beschreibt den Werdegang dieser weltbedeutenden Rinderrasse, ihren Ursprung und ihre Entwicklung bis in die Gegenwart. Insbesondere seit der Mitte des 19. Jahrhunderts entstand diese Rasse durch Einkreuzung Schweizer Simmentaler in Landschlage Süd- und Mitteldeutschlands. Da Bayern den gröBten Fleckviehbestand und -anteil in Deutschland besitzt, erklart dies auch die bayerische Prägung des Buches und dic weniger tiefgrändige Beschreibung des Fleckviehs in den anderen Zuchtgebieten Deutschlands oder des Auslandes.

In 16 Abschnitten wird die Biographie dieser Rasse vorgestellt. Die einleitenden Kapitel beschreiben vor allem die historischen Ablăufc, Genannt seien die lokalen Schlåge und Rassen, das Simmentaler Rind oder die geschichtliche Entwicklung der Fleckviehzucht sowie der Aufbau der organisierten Fleckvichzucht in Deutschland und angrenzenden Ländern. Es folgen die Abschnitte Zuchtziel und Zuchityp im Wandel der Zeit sowie die Entwicklung der Nutzleistungen beim Fleckvieh. Den Abschnitten Rinderleistungsbücher und Exterieurbeurieilungen folgen die Darstellung neuer Biotechniken und Zuchtmethoden, die Entwicklung wichtiger Fleckviehblutlinien, Seuchenbekåmpfung, Vermarktung, Schauen und Ausstellungen sowie Tierzuchtrecht. In einigen Abschnitten hätte man sich bei dem hohen Anspruch dieses Buches eine ausfuhrlichere Beschreibung auch anderer als bayerischer Standorte gewïnscht, das gilt teilweise auch für die ausgewăhlte Literatur. Der letzte Abschnitt widmet sich einer Standortbestimmung der Fleckviehzucht im 21, Jahrhundert in Deutschland, Europa und weltweit. Ein Anhang nennt Vorsitzende und Zuchtleiter deutscher Fleckvieh-Zuchtverbănde, eine besondere Ehre fur diejenigen, die sich in zurllckliegenden Jahrzehnten tatkräftig und überzeugend fur diese Rasse engagierten. Ein ausgewăhltes Tabellenwerk informiert uber Bestandsentwicklungen sowie Ergebnisse der Milchleistungsprafung von drei süddeutschen Zuchtgebieten. In vorliegendem Buch wird gezeigt, dass die Verbesserung von Milch- und Fleischleistung dieses. Zweinutzungsrindes insbesondere bei letzterer die Fleckviehzucht zu einem gefragten Markenzeichen in aller Welt - einer Weltrasse - hat werden lassen..

Dieses sehr gut aufgemachte Buch, einschließlich der schönen und aussagefahig ausgewălten, zahlreichen, hervorragenden Abbildungen, die jedem Betrachter Freude bereiten, setzt dieser Rasse ein bleibendes Denkmal. Es ist nicht nur fur passionierte Zuchter interessant, informativ und unverzichtbar, sondern zeigt auch die Typund Leistungsentwicklung im Ergebnis von Umwelt und konsequenter Zuchtarbeit in unterschiedlichen Zuchtgebieten und Zeitabläufen. Dieses Standardwerk filgt sich wïrdig in die Reihe vorhandener bekannter Rassenbiographien ein und bedarf eigentlich keiner besonderen Empfehlung, 